\title{
DISKUSIE
}

\section{POZNÁMKY K ONOMASTICKÝM KONCEPCIÁM}

\author{
VINCENT BLANÁR
}

Bemerkungen zu den onomastischen Konzeptionen. Jazykovedný časopis, 2009, Vol 60, No. 2 , pp. 155 - 158. (Bratislava)

Die Untersuchung der Eigennamen nach verschiedenen Aspekten bringt die Erkenntnis ihrer verschiedenen Seiten näher. Einige Fragen werden jedenfalls ungleich erklärt, beziehungsweise bleiben ungelöst. Die ungleiche Auffassung des Status der Eigennamen hängt mit der ungleichen Auffasung der Schlüsseltermine zusammen. Man formulierte den linguistischen (J. Kuryłowicz), den linguistischen und onomastischen (V. Blanár) und naturwissenschaftlichen (E. Hansack) Status. W. Van Langendonck hält sich an der pragmatisch-semantisch-syntaktischen Theorie fest. Neue Seitenblicke und Zusammenhänge enthüllt der struktur-funktionelle und kommunikativ-pragmatischen Zutritt. V. Blanár bestimmte die onymische Nomination als gesellschaftlich bedingte Identifikation und Differentitation eines Gattungseinzelwesens. Der Eigenname als Sprachzeichen sui generis kennzeichnet sich in der Rede durch die referentille Identifikation und in der Tiefstruktur durch die präsuppositionelle (systemhafte) Identifikation. Der Seitenblick in die Tiefstruktur in der Anthroponymie ermöglicht die Bestimmung des Funktionsgliedes. Mit dem Funktionsglied verstehe ich den (unterschiedlichen). Inhalt einzelner onymischen Klassen. Die Bestimmung derFunktionsglieder führt zur tieferen Erkenntnis der Strukturierung der Personenbenennung. (Dieser Zutritt ist für die slowakische Onomastik charakteristisch). Unter historischem und methodologischem Standpunkt ist die Theorie der Rekonstruktion und des Rekurses bedeutungsvoll 1 .

Počet príspevkov, ktoré publikovali vydavatelia „učebnice pre štúdium onomastickej literatúry“ Andrea Brendler a Silvio Brendler v záslužnom diele Namenarten und ihre Erforschung (2004), obsahuje niekol'ko tisíc jednotiek. Ide o takmer neprehl'adný súbor odborných prác, ktoré sa zaoberajú rozličnými stránkami vlastných mien. Výskum vlastných mien z rozličných aspektov priblížil poznanie ich rozličných stránok, avšak niektoré (aj základné) otázky sa vykladajú nerovnako, prípadne ostávajú nedoriešené.

Nerovnaké chápanie statusu vlastného mena súvisí s nerovnakým chápaním kl'účových termínov. Formuloval sa status lingvistický (1), lingvistický a onomastický (2) a prírodovedný (3). Do prvej skupiny možno zaradit’ aj americký konštruktivizmus, ktorý reprezentuje monografické dielo Willyho Van Langendoncka Theory and typology of propre names (2007).

Jerzy Kuryłowicz (1956) pokladá za podstatný lingvistický status vlastných mien; pri tom poukazuje na ich niektoré osobitné črty. Vincent B la nár (1976) 
vymedzuje propriá ako osobitnú pomenovaciu oblast' a $\mathrm{k}$ ich lingvistickému statusu pridáva onomastický status. Vzhl’adom na špecifické vlastnosti proprií sa totiž táto kategória vydel'uje ako osobitná pomenovacia oblast' $\mathrm{s}$ dvojitým začlenením. Proprializáciou pomenovania druhových jedincov sa neruší súvzt'ažnost' vlastného mena s jeho príslušným druhom. Pomenovanie druhových jedincov sa uskutočňuje na pozadí ich druhu; porov. (rieka) Dunaj, (pohorie) Karpaty, (priezvisko) Adamčík. Jednotlivé implicitne obsahuje aj všeobecné, propriálnost' sa neodtŕha od apelatívnosti. To je charakteristický znak štruktúrovanosti slovnej zásoby jazyka.

Aleksandra V. S uperanskaja $(1973$, 1986) vyslovuje názor, že vlastné mená nemajú $\mathrm{v}$ jazyku špecifickú funkciu, avšak onomastika presahuje rámec lingvistiky. Má istú samostatnost' vzhl'adom na mimolingvistické zložky. Pri pomenúvaní druhových jedincov propriom vztah $\mathrm{k}$ nadradenej triede pretrváva; porov. (mesto) Košice, (vrch) Kriváñ. Celkove však ide o lingvistický ráz onomastických analýz. Vd'aka užšiemu denotatívnemu spojeniu vlastných mien sa onomastika sčasti odlišuje od všeobecnej lingvistiky. Je to relatívne samostatná oblast' jazykovedy. No vlastné mená predstavujú neoddelitel'nú súčast' každého lingvistického výskumu a opisu. Pretože vlastné mená nemajú špecifické funkcie, treba zamerat' pozornost' na ich informačnú stránku, napr. poukaz na príbuzenské vzt’ahy, sociálnu podmienenost', pôvod mena a pod.

Ernest Hansack (1990, 2004) vypracoval prírodovedný (kognitivistický) prístup s chápaním vlastného mena ako informačnej množiny o pomenovanom objekte. Význam vlastného mena vymedzuje ako súbor dát, ktoré meno indikuje. Podl'a E. Hansacka je jediný a podstatný rozdiel medzi apelatívom a propriom rozdiel kvantitatívny. Apelatíva označujú objekty z otvorených tried, kým propriá označujú triedy len s jedným objektom (indivíduá).

Predstavitel' amerického konštruktivizmu W. Van Langendonck (2007) sa pridŕža spojenej pragmaticko-sémanticko-syntaktickej teórie. Onomastika tvorí súčast' lingvistickej analýzy, ale pri vlastnom mene hovorí Langendonck o odlišnom (presupozičnom) druhu významu; odlišuje významy: kategoriálny (osoba, osada, rieka, vrch...), asociatívny, emotívny a gramatický (napr. deklinácia). Uvedomuje si, že pri vlastných menách sa nestráca poukaz na príslušnú triedu. Vlastné mená tvoria kontinuálnu ret’az od prototypových mien cez neprototypové po prechodné. Avšak o vlastné meno podl'a Langendocka ide len pri realizácii referenčného vzt’ahu. Podobne, ako je to obvyklé u západoeurópskych bádatel'ov (porov. napr. známu monografiu Wernera Kany ho Inoffizielle Personennamen. Bildung, Bedeutung und Funktion, 1992), analyzuje meno ako také v rozličných použitiach, ale nie ako prvok danej onymickej triedy (podsystému). K poznaniu a odlíšeniu funkčných členov osobných mien sa nedopracoval.

Nové pohl'ady a súvislosti odhal'uje funkčno-štruktúrny a pragmaticko-komunikačný prístup. Onymickú nomináciu chápeme ako spoločensky podmienenú identifikáciu, resp. diferenciáciu druhových jednotlivín. Základnú paradigmu funkčnej 
onomastiky tvorí systémovost', normovanost', komunikatívna viazanost' pomenovania a jazykovo i spoločensky podmienená dynamika komunikačného procesu (porov. aj Šrámek, 2004). Vlastné meno má dvojaký status: lingvistický a onomastický. Ako jazykový znak sui generis sa vyznačuje v reči referenčnou identifikáciou a v híbkovej štruktúre presupozičnou (systémovou) identifikáciou (tvorí ju súbor onymických príznakov). Sú to dve stránky jednej mince. Pohl'ad do híbkovej štruktúry v antroponymii umožňuje poňatie funkčného člena; funkčným členom rozumieme odlišný obsah jednotlivých antroponymických tried (podsystémov). Obsahom týchto tried sú odlišné súbory onymických príznakov. Krstné meno, priezvisko, prímeno, prezývka, individuálna charakteristika predstavujú osobitné funkčné členy. Napr. priezvisko odlišujú od krstného mena príznaky „dedičnost““ a ,príbuzenský vzt’ah“. Preto je priezvisko hierarchicky základným členom úradnej pomenovacej schémy. Vymedzenie funkčných členov osobných mien vedie k hlbšiemu poznaniu štruktúrovanosti osobného pomenúvania. Tento teoretický prístup - charakteristický pre slovenskú onomastiku - umožňuje vysvetlit' napr. mechanizmus prechodu od jednomennosti k dvojmennosti, klasifikovat' bohato členené neúradné (živé) mená a zdôvodnit' úradné mená typu Pavel PAVEL (Blanár, 2009, s. 75 - 76) - tento problém doteraz nebol riešený. $Z$ historického i metodologického hl'adiska je prínosná problematika rekonštrukcie (porov. Eichler, 1988) a rekurzu (porov. Šrámek, 1990, 1999). Rekonštrukciou sa zist’uje predpokladaná východisková podoba mena. Metóda rekurzu ráta s existenciou propriálnej sféry jazyka. Zameriava sa na zistenie predpokladanej formy propria v jeho možnej modelovej podobe. Pri tom sa vychádza zo zákonitostí propriálne pomenovacích procesov. Systémový priestor sa manifestuje $\mathrm{v}$ časových vrstvách, $\mathrm{v}$ priestorových areáloch a v kvantitatívnych rozmeroch. Základnú pracovnú metódu novodobej onomastiky predstavuje propriálny jazykový zemepis.

\section{Bibliografia}

BLANÁR, Vincent: Lingvistický a onomastický status vlastného mena. In: Onomastica, 21, 1976, s. $5-18$.

BLANÁR, Vincent: Poznámka k referenčnej a systémovej identifikácii. In: Slavica Slovaca, 2009, roč. 44 , s. $75-76$.

EICHLER, Ernst: Probleme der onomastischen Rekonstruktion als linguistisches Universale. In: Probleme der Namenbildung. Rekonstruktion der Eigennamen und der ihnen zugrunde liegenden Appellative. Upsala 1988, s. $91-103$.

HANSACK, Ernst: Bedeutung, Begriff, Name. Studia et exempla linguistica et philologica. Series II: Studia minora I. Ed. K. Trost. Tom I. Regensburg: S. Roderer Verlag 1990. 95 s.

HANSACK, Ernst: Das Wesen des Namens. In: Namenarten und ihre Erforschung. Ein Lehrbuch für das Studium der Onomastik. Eds. A. Brendler und S. Brendler. Hamburg: Baar 2004, s. 51 - 65.

KANY, Werner: Inoffizielle Personennamen. Bildung, Bedeutung und Funktion. Tübingen, Niemeyr 1992. $365 \mathrm{~s}$.

KURYŁOWICZ, Jerzy: La position linguistique du nom propre. In: Onomastica 2, 1956, s. 1 14.

Jazykovedný časopis, 60, 2009, č. 2 
LANGENDONCK, Willy Van: Theory and Typology of Proper Names. Trends in Linguistics, Studies and monographs 168, Berlin - New York: Mouton de Gruyter 2007. 378 s.

Namenarten und ihre Erforshung. Ein Lehrbuch für das Studium der Onomastik. Eds. A. Brendler und S. Brendler. Hamburg: Baar 2004. 1024 s.

SUPERANSKAJA, Aleksandra V.: Obščaja teorija imeni sobstvennogo. Moskva: Izd. Nauka 1973. $366 \mathrm{~s}$.

SUPERANSKAJA, Aleksandra V. et al.: Teorija i metodika onomastičeskich issledovanij. Red. A. P. Nepokupnyj. Moskva 1986. 249 s.

ŠRÁMEK, Rudolf: Zur onomastischen Rekursion. In: Studia onomastica 6 (Ernst Eichler zum 60. Geburstag). Namenkundliche Informationen, Beiheft 13/14, Leipzig, 1990, s. 39 - 52.

ŠRÁMEK, Rudolf: Úvod do obecné onomastiky. Brno: Vydavatelství Masarykovy univerzity 1999. 191 s. +19 máp.

ŠRÁMEK, Rudolf: Etymologie und Deutung in der Namenkunde. In: Namenarten und ihre Erforschung. Ein Lehrbuch für das Studium der Onomastik. Eds. A. Brendler und S. Brendler. Hamburg: Baar 2004, s. 93 - 106. 